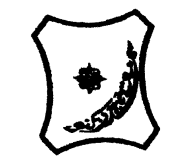

Bayero Journal of Pure and Applied Sciences, 10(1): 345 - 349

ISSN 2006 - 6996

\title{
DROUGHT AFFECTS PROTEIN AND PHENOLIC CONTENT IN BAMBARA GROUNDNUT (Vigna subterranea L. VERDC.)
}

\author{
Inuwa, R.S. and *Muhammad, Y.Y. \\ Department of Biochemistry, Bayero University, Kano, Nigeria. \\ Corresponding author: yymuhammad.bch@buk.edu.ng
}

\begin{abstract}
Bambara groundnut (Vigna subterranea L. Verdc.) is a legume crop, which has long been recognised as a protein-rich and drought-tolerant crop, used extensively in sub-Saharan Africa. This study evaluates the effect of experimental water deficit stress on total protein concentration, secondary protein structure and the total phenolics content on three Bambara groundnut landraces. Plants were grown in pots in a screen house. Water deficit was induced at the vegetative stage by withholding irrigation while fully watered plants served as control. Predominantly, B-sheet structure was observed in all the stressed as well as the control plants even though differences were observed between the treatments. Water deficit stress led to significant $(P<0.05)$ increase in total protein content, but total phenolics content in all the landraces increased slightly. Drought stress induced significant increase in the synthesis of various proteins as part of the response strategy. The slight increase in total phenolics in the leaves of drought-stressed plants might be related to the antioxidant defence role of the phenolics. Correlation analysis of the total protein and phenolics indicated a strong positive relation across the three landraces studied. The results of the present work points to the resilience of the Bambara groundnut species to water deficit.

Keywords: Bambara groundnut, water-deficit, protein content, phenolics, FTIR spectroscopy
\end{abstract}

\section{INTRODUCTION}

Bambara groundnut (Vigna subterranea L. Verdc.) is an indigenous African leguminous crop grown primarily for its seeds and is increasingly becoming popular as food in rural areas across the African continent. It is the third most commonly eaten legume after groundnut (Arachis hypogea) and cowpea (Vigna unguiculata) (Omoikhoje, 2008). Bambara groundnut is primarily grown for its seeds and has diverse uses. It is economically important because it is an inexpensive source of high quality protein. The Bambara groundnut seeds have relatively high protein content with high lysine content (Adu-Dapaah and Sangwan, 2004), so has a beneficial complementary effect when consumed together with cereals, which have low lysine content (Massawe et al., 2005). The essential amino acid proline of the seed is comparable to that of soybean (Omoikhoje, 2008).

Bambara groundnut is widely regarded as drought tolerant (Linnemann and Azam-ali, 1993; Muhammad et al., 2016). Collinson et al. (1997) suggested that drought tolerance of Bambara groundnut is a result of osmotic adjustment and low water loss through stomatal closure. Variation in protein contents is an essential part of plant response to environmental stress as well as for plants adaptation to changes in environmental conditions (Vierstra, 1993; Hieng et al., 2004). Among the proteins synthesized in response to drought stress are dehydrins (dehydration induced) which belong to the late embryogenesis abundant proteins (Close and Chandler, 1990). The exact role of dehydrins in the plant has yet to be determined, but expression of dehydrins has long been correlated with several abiotic stressors including drought, salinity and cold.

With its nutritional attributes, Bambara groundnut is still among the lesser known and under-utilized crops. Similarly, despite its known drought tolerance, the mechanism is yet to be fully elucidated. This research study was carried out to evaluate the effect of waterdeficit stress on protein concentration, total phenolics and secondary protein structure on Bambara groundnut.

\section{MATERIALS AND METHODS}

Three landraces of Bambara groundnut from different parts of Northern Nigeria (Gombe, Kano and Katsina) were used in the study. Treatments were initiated at the vegetative stage of development. Drought was induced by withholding irrigation in potted plants while $40 \%$ polyethylene glycol (PEG 10000) was used to induce drought in leaf discs $(1 \mathrm{~cm}$ diameter). 
Control plants were fully irrigated throughout the experimental period. The experimental plants were arranged in a completely randomised design.

Protein was extracted using the TCA/acetone method reported by Mechin et al. (2003); total protein content was determined using Bradford assay. Total phenolics content was estimated using Folin-Ciocalteau reagent (Siddhuraju and Becker, 2003). Fourier Transform Infrared (FTIR) spectrometry was performed using an FTIR spectrometer (Cary 630, Agilent Technologies).

Statistical mean and standard deviation were computed for four replicates in each treatment group. Analysis of variance was also performed using Instat statistical package (Graphpad, California,USA).

\section{RESULTS AND DISCUSSION}

The total phenolics content of the three Bambara groundnut landraces studied are presented in Table 1 . In all the landraces subjected to drought stress, phenolics content was slightly higher than that in well-watered plants. Similarly, the change in total phenolics in the stressed plants across the landraces was only slightly different. There was a significantly $(P<0.05)$ higher total protein concentration in stressed compared to the control plants in all the landraces. Differences were also observed between the different landraces studied (Table 1). The phenolics content correlated well positively with the total protein content $(R=$ 0.988).

Table 1: Concentrations of total phenolics and total protein content of three Bambara groundnut landraces after drought stress of 16 days.

\begin{tabular}{|c|c|c|c|c|c|c|c|c|c|}
\hline & \multicolumn{2}{|r|}{ Landrace-1 } & \multicolumn{4}{|c|}{ Landrace-2 } & \multicolumn{3}{|c|}{ Landrace-3 } \\
\hline & Stressed & Control & Stressed & & Control & & Stressed & & Control \\
\hline $\begin{array}{l}\text { Total } \\
\text { Phenolic } \\
\mathrm{s} \quad(\mathrm{m} \\
\mathrm{GAE} / \mathrm{g})\end{array}$ & $\begin{aligned} & 0.36 \\
= & 0.038 \\
g & \end{aligned}$ & $\pm 0.34 \pm 0.006$ & $\begin{array}{l}0.37 \\
0.006\end{array}$ & \pm & $\begin{array}{l}0.35 \\
0.006\end{array}$ & \pm & $\begin{array}{l}0.38 \\
0.020\end{array}$ & \pm & $0.35 \pm 0.006$ \\
\hline $\begin{array}{l}\text { Total } \\
\text { Protein } \\
\text { (mg/dl) }\end{array}$ & $\begin{array}{l}3.18^{\mathrm{a}} \\
0.026\end{array}$ & $\pm 0.08^{\mathrm{a}} \pm 0.015$ & $\begin{array}{l}3.68^{\mathrm{b}} \\
0.116\end{array}$ & \pm & $\begin{array}{l}0.14^{\mathrm{b}} \\
0.032\end{array}$ & \pm & $\begin{array}{l}3.27^{c} \\
0.174\end{array}$ & \pm & $0.06^{\mathrm{c}} \pm 0.006$ \\
\hline
\end{tabular}

Values with the same superscripts in the same column are significantly different $(P<0.05)$. Quantitative differences in different landraces of Bambara groundnut leaves under water deficit stress have been observed. The result indicates that drought stress might have led to increased synthesis of phenolic compounds as a response to the oxidative stress (Navarro et al., 2006). The content of phenolic compounds has been reported to increase as a consequence of drought stress in many plant species (Hura et al., 2012). Phenolic compounds are known to have anti-oxidant properties and play an important role in conferring resistance to environmental stresses (Farooq et al., 2013).

Protein synthesis and turnover is one of the fundamental metabolic processes for plants to cope with drought stress. Proteomic investigations have shown that a significant proportion of drought-responsive proteins in leaves are attributed to protein synthesis and turnover functions. Most of them exhibited an increase under drought stress, which would be beneficial for protein synthesis in response to specific drought conditions (Hieng et al. 2004; Tian et al., 2013). Among the proteins synthesized in response to drought stress are dehydrins (dehydration induced), they accumulate in a wide range of plant species under dehydration stress Close and Chandler, 1990. Drought regulation of dehydrin gene expression was observed in both droughttolerant and drought-susceptible plant cultivars (Cellier et al., 1998). A proposed role of dehydrin-like proteins in drought stress has been the protection cells from dehydration stress. Dehydrin-like proteins may also have a role similar to compatible solutes (such as proline and glycine-betaine) in osmotic adjustment. Another possible role of stress proteins is to bind with the ions accumulated (ion sequestering) under drought stress and to control solute concentration in the cytoplasm (Dure, 1993). 
Special Conference Edition, November, 2017

Table 2: Concentrations of total protein $(\mathrm{mg} / \mathrm{dl})$ in Bambara groundnut leaf discs suspended in distilled water (control) and in $40 \%$ polyethylene glycol (PEG; drought stressed) at different time intervals.

\begin{tabular}{lllll}
\hline & Control & 1 hour & 2 hour & 6 hour \\
\hline Landrace-1 & $0.98 \pm 0.010$ & $0.98 \pm 0.006$ & $0.99 \pm 0.006$ & $0.97 \pm 0.006$ \\
Landrace- 2 & $0.99 \pm 0.015$ & $0.97 \pm 0.010$ & $0.97 \pm 0.006$ & $0.99 \pm 0.042$ \\
Landrace-3 & $0.98 \pm 0.006$ & $0.97 \pm 0.006$ & $0.98 \pm 0.000$ & $1.00 \pm 0.006$ \\
\hline
\end{tabular}

Values are mean \pm standard deviation, $n=3$.

In leaf discs chemically induced with waterdeficit stress, variance analysis for total protein showed insignificant variation between the stressed and control plants. This observation might suggest that an equivalent water deficit in the plant cells was not attained under the chemically induced stress, unlike the case of the potted plants. This might be scientifically ascribed to the strength or concentration of PEG used or too short a duration of the treatment or both. PEG has been widely used to induce experimental drought stress in many plant species (Kocheva et al., 2009; Tian et al., 2013).

Table 3: Protein secondary structure analysis of FTIR spectral assignment in Bambara groundnut Landrace-1.

\begin{tabular}{|c|c|c|c|}
\hline & $\begin{array}{l}\text { Frequency } \\
\text { range }\left(\mathrm{cm}^{-1}\right)\end{array}$ & Description * & Structure of protein \\
\hline \multirow[t]{2}{*}{$\begin{array}{l}\text { Landrace- } \\
1 \text { (control) }\end{array}$} & $3253-3260$ & Amide $\mathrm{A}(\mathrm{N}-\mathrm{H}$ stretch $)$ & \\
\hline & 1640 & Amide I ( $C=0$ Stretching) & B-sheet (1625 -1640) \\
\hline \multirow{5}{*}{$\begin{array}{l}\text { Landrace- } \\
1 \text { (stressed) }\end{array}$} & $3257-3331$ & Amide $\mathrm{A}(\mathrm{N}-\mathrm{H}$ stretch $)$ & \\
\hline & 2128 & $\mathrm{C} \equiv \mathrm{C}$ stretch & \\
\hline & $1640-1700$ & Amide I ( $\mathrm{C}=0$ Stretching) & B-sheet $(1625-1640)$ \\
\hline & $\begin{array}{l}1428 \\
1372-1376\end{array}$ & $\mathrm{C}-\mathrm{H}$ bend & \\
\hline & 1241 & $\begin{array}{l}\text { Amide III (CN stretching, } \mathrm{NH} \\
\text { bending). }\end{array}$ & \\
\hline
\end{tabular}

${ }^{*}$ Kong and Yu (2007).

Table 4: Protein secondary structure analysis of FTIR spectral assignment in Bambara groundnut Landrace-2.

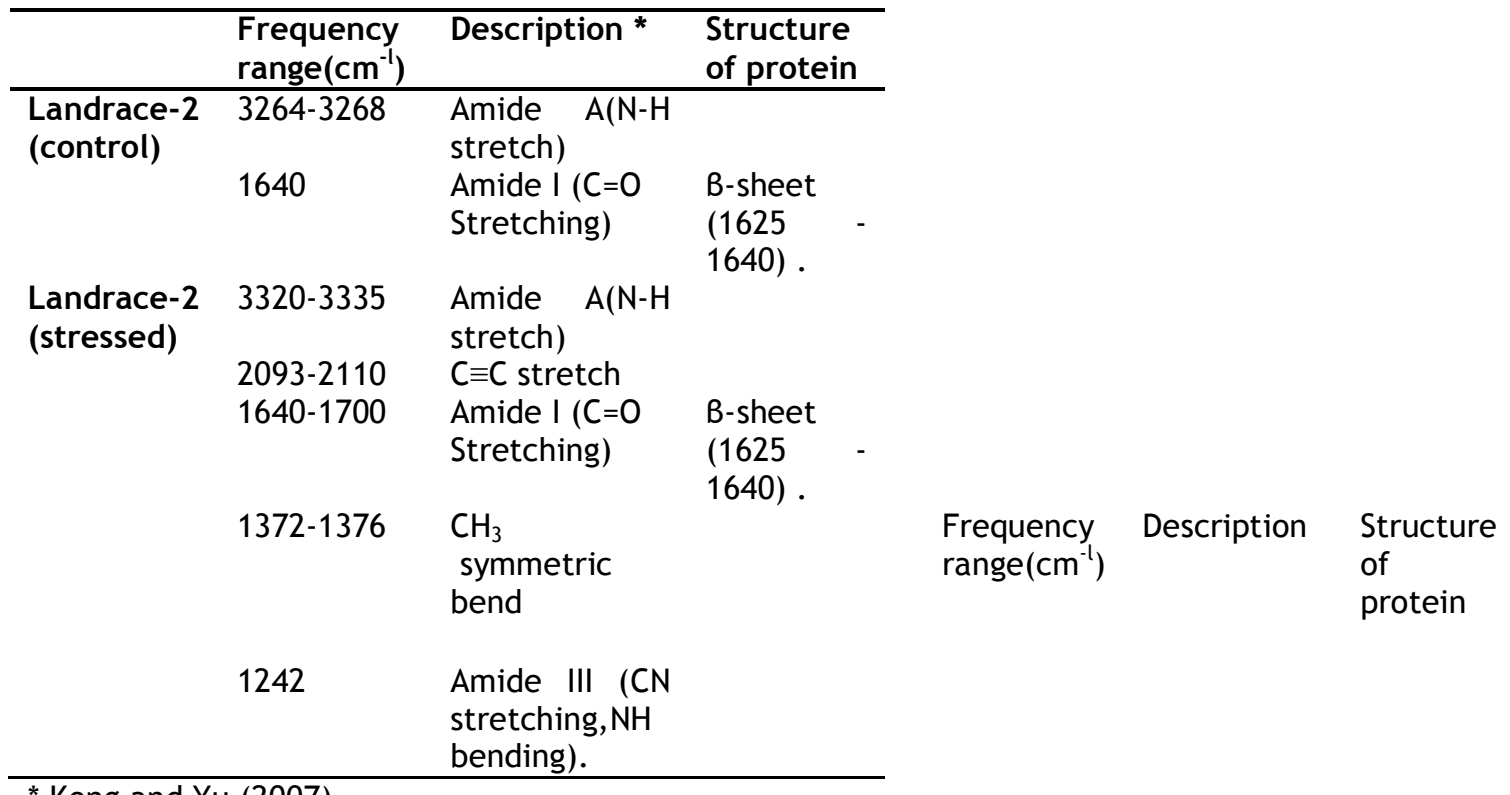


Table 5: Protein secondary structure analysis of FTIR spectral assignment in Bambara groundnut Landrace-3.

\begin{tabular}{|c|c|c|c|c|c|}
\hline & $\begin{array}{l}\text { Frequency } \\
\text { range }\left(\mathrm{cm}^{-1}\right)\end{array}$ & Description * & $\begin{array}{l}\text { Structure } \\
\text { protein }\end{array}$ & & of \\
\hline \multirow{2}{*}{$\begin{array}{l}\text { Landrace-3 } \\
\text { (control) }\end{array}$} & $3260-3272$ & Amide $\mathrm{A}(\mathrm{N}-\mathrm{H}$ stretch) & & & \\
\hline & 1640 & Amide I ( $\mathrm{C}=\mathrm{O}$ stretching) & $\begin{array}{l}\text { B-sheet } \\
\text { 1640) }\end{array}$ & $(1625$ & - \\
\hline \multirow{4}{*}{$\begin{array}{l}\text { Landrace-3 } \\
\text { (stressed) }\end{array}$} & $3268-3339$ & Amide $\mathrm{A}(\mathrm{N}-\mathrm{H}$ stretch $)$ & & & \\
\hline & 1640 & Amide I ( $\mathrm{C}=\mathrm{O}$ stretching) & $\begin{array}{l}\text { B-sheet } \\
\text { 1640). }\end{array}$ & $(1625$ & - \\
\hline & 1376 & $\mathrm{CH}_{3}$ symmetric bend & & & \\
\hline & 1242 & $\begin{array}{l}\text { Amide III (CN stretching, } \mathrm{NH} \\
\text { bending). }\end{array}$ & & & \\
\hline
\end{tabular}

* Kong and Yu (2007).

FTIR analysis of the proteins extracted from the leaves of the treated plants did not show any significant changes in the secondary structure (Tables 3 - 5). FTIR spectroscopy absorption bands in both control and stressed plants across the three studied landraces generally correspond to $\mathrm{N}-\mathrm{H}$ and Amide $\mathrm{I} \mathrm{C}=\mathrm{O}$ stretching vibrations, which are mainly from the protein peptide bonds . In addition to these, additional peaks were observed in stressed compared to control plants. For example, in landrace-1 (Table 3), four additional peaks were seen; the band at $2128 \mathrm{~cm}^{-1}$ which represents $\mathrm{C} \equiv \mathrm{C}$ stretching vibrations, 1428 ( $\mathrm{C}-\mathrm{H}$ bend), 1372$1376\left(\mathrm{CH}_{3}\right.$ symmetric bend) and 1241 (CN stretching, $\mathrm{NH}$ bending of amide III).

The absorption band of the amide I stretching vibrations of the amide group depends on the nature of hydrogen bonding between the amide I and amide II moieties and is particularly useful for determining the protein secondary structure (Surewicz et al., 1988). A peak in the region between $1640 \mathrm{~cm}^{-1}$ and $1650 \mathrm{~cm}^{-1}$ indicates unstructured elements and a peak at around $1620 \mathrm{~cm}^{-1}$ is associated with intermolecular Bsheet aggregates (Wilder et al., 1992). Thus the

\section{REFERENCES}

Adu-Dapaah, H.K. and Sangwan, R.S. (2004). Improving bambara groundnut productivity using gamma irradiation and in vitro techniques. Afr. J. Biotechnol. 3: 260-265.

Cellier, F., Conejero, G., Breitler, J. C.and Casse, F. (1998). Molecular and physiological responses to water deficit in drought-tolerant and droughtsensitive lines of sunflower. Accumulation of dehydrin transcripts correlates with tolerance. Plant Physiol. 116, 319-328.

Close, T.J. and Chandler, P.M. (1990). Cereal dehydrins: Serology, gene mapping, and protein structure analysis indicates that B-sheet structure is predominantly the structure of the proteins in all the stressed and control potted plants, as well as the leaf discs across all the three landraces. This implies that the protein secondary structure was not affected by the drought stress. This may be due to the presence of some protein that helps to stabilise the structure. Generally, B-sheet structure was observed in both stressed and control plants. Maintenance of protein structure is important to maintain cell functionality when the intracellular concentration of water becomes very low (Valliyodan and Nguyen, 2006).

\section{CONCLUSION}

Drought stress induced significant increase in protein synthesis, but slight increase in total phenolics in the leaves of drought-stressed plants of all the three landraces of Bambara groundnut. The protein secondary structure is not affected by the drought stress in all the three landraces. Even though differences in response were observed across the three Bambara groundnut landraces studied, the findings are generally indicative of the hardiness of the species to water deficit.

potential functional roles. Aust. J. Plant Physiol. 17: 333-344.

Collinson, S.T., Clawson, E.J., Azam-Ali S.N. and Black, C.R. (1997). Effects of soil moisture deficits on the water relations of Bambara groundnut (Vigna subterranea L. Verdc.). J. Exp. Bot. 48: 877-884

Dure, L. (1993). Structural motifs in Lea proteins. In T.J. Close, E.A. Bray, eds, Plant Responses to Cellular Dehydration during Environmental Stress. Current Topics in Plant Physiology, Vol 10. American Society of Plant Physiologists, Rockville, MD, pp 91-103. 
Farooq, M., Irfan, M., Aziz, T., Ahmad, I. and Cheema, S. (2013). Seed priming with ascorbic acid improves drought resistance of wheat. J. Agron. Crop Sci. 199.1: 12-22.

Hieng, B., Ugrinovich, K., Sustar-Vozlich, J. and Kidric, M. (2004). Different classes of proteases are involved in the response to drought of Phaseolus vulgaris cultivars differing in sensitivity. J. Plant Physiol. 161: 519-530.

Hura, T., Hura, K., Dziurka, K., Ostrowska, A., Bączek-Kwinta, R. and Grzesiak, M. (2012). An increase in the content of cell wall-bound phenolics correlates with the productivity of triticale under soil drought. J. Plant Physiol. 169(17): 1728-1736.

Kocheva, K., Kartseva, T., Landjeva, S. and Georgiev, G. (2009). Parameters of cell membrane stability and levels of wheat seedlings treated with PEG 6000. Gen. Appl. Plant Physiol. 35.3-4 (2009): 127133.

Kong, J. and Yu, S. (2007). Fourier transform infrared spectroscopy analysis of protein secondary structures. Biochim. Biophys. Acta 39: 549-559.

Linnemann, A.R. and Azam-ali, S.N. (1993). Bambara Groundnut (Vigna subterranea). In: Williams, J.T., (Ed). Pulses and Vegetables. Chapman and Hall, London, pp: 13-58.

Massawe, F.J., Mwale, S.S., Azam-Ali, S.N. and Roberts, J.A. (2005). Breeding in Bambara groundnut (Vigna subterranea L. Verdc): Strategic considerations. Afr. J. Biotechnol., 4: 463-471.

Mechin, V., Damerval, C. and Zivy, M. (2003). Methods in Molecular Biology. Plant Proteomics: Methods and Protocols Vol. 335.

Muhammad, Y.Y., Mayes, S. and Massawe, F. (2016). Effects of short-term water deficit stress on physiological characteristics of Bambara groundnut
(Vigna subterranea (L.) Verdc.). S. African J. Plant and Soil, 33:1, 51-58.

Navarro, J.M., Flores, P., Garrido, C. and Martinez, V. (2006). Changes in the contents of antioxidant compounds in pepper fruits at ripening stages, as affected by salinity. Food Chem. 96:6673.

Omoikhoje, S. O. (2008). Assessment of the nutritive value of Bambara groundnut as influenced by cooking time. Livest. Res. Rural Dev., 20 (4).

Siddhuraju, P. and Becker, K. (2003). Antioxidant properties of various solvent extracts of total phenolic constituents from three different agroclimatic origins of drumstick tree (Moringa oleifera Lam.) leaves. J. Agric Food Chem. 51(8) : 2144-2155.

Surewicz, W.K. and Mantsch, H.H. (1988). New insight into protein structure from resolution enhanced infrared spectra, Biochim. Biophys. Acta 952 115-130.

Tian, F., Gong, J., Zhang, J., Zhang, M., Wang, G., Li, A. and Wang, W. (2013). Enhanced stability of thylakoid membrane proteins and antioxidant competence contribute to drought stress resistance in the tasg1 wheat stay-green mutant. J. Exp. Bot. 64.6: 1509-1520.

Valliyodan, B. and Nguyen, H.T.. (2006). Understanding regulatory networks and engineering for enhanced drought tolerance in plants. Curr. Opin. Plant Biol. 9.2: 189-195.

Vierstra, R. D. (1993). Protein degradation in plants. Annual Review of Plant Physiol. Plant Molecular Biol.44: 385-410.

Wilder, C.L., Friedrich, A.D., Potts, R., Daumy,G. and Francoceur, M.L. (1992). Secondary structure analysis of two recombinant murine proteins, interleukin 1a and 1B: is infrared spectroscopy sufficient to assign structure? Biochemistry, 31: 27-31. 